\title{
Excess consumption of Lavana Rasa (Salty taste) - A cause of Amlapitta (Hyperacidity)
}

\author{
Research Article
}

\section{Joshi Mrudula Vinayak ${ }^{*}$, Shendye Hemangi Vasudeo², Bhole Nilima ${ }^{3}$, Joshi Vinayak ${ }^{4}$}

\section{Professor and HOD, 2. Assistant Professor, Department of Ayurved Samhita Siddhanta,}

4. Professor and HOD, Department of Rognidan evam Vikrutvigyan

Dr D.Y.Patil college of Ayurved and Research centre, Pimpri, Pune. India.

Dr. D.Y. Patil Vidyapeeth (Deemed to be University), Pune, Maharashtra, India.

3. Ayurveda practitioner, Nerul, Navi Mumbai. India.

\begin{abstract}
Amlapitta (Hyperacidity) is one of the ever growing diseases observed in society. Intake of salt in excess can lead into Amlapitta due to its Vidahi and Agneya property. Foods like cheese, chips, sauces, buttermilk, etc. contains variety of salts including common salt. The disease Amlapittal Amlika can be interpreted as Hyperacidity; is not separately described in Samhita, but mentioned as Lakshana (symptom) of Atiyoga (excessive intake) of Lavana Rasa. Hence an observational study was designed. Aim: To examine whether Atiyoga of Lavana Rasa (common salt) can be a Hetu (causative factor) of Amlapitta. Methodology: Study included 100 identified patients of Amlapitta; both males and females from the age group of 20-60 years suffering from Amlodgar (sour blenching) as the predominant symptom. A structured, pilot tested 6 item questionnaire was used to collect data. Statistical Analysis: Descriptive data was analyzed using number and percentage. Results: Maximum patients were from 20-29 years age group; with Kapha-Pittaja Prakruti (77.78 \%) and Pitta-Kaphaja Prakruti (68.75\%) who used to consume Lavana rasa in variety of type and in excess quantity. Family history of the disease Amlapitta showed maximum \% in female patients as $31.03 \%$ whereas only $4.76 \%$ males suffered from the disease. Liking towards Lavana, Katu and Amla rasa in population was found to be $36 \%, 28 \%, 16 \%$ respectively. In causative factors of Amlapitta, Lavana Rasadhikya was noted in 62 patients whereas Vidahi Anna followed by spicy food and oily food was found in 60, 58, 56 number of patients respectively. Conclusion: From the study, it is observed that there is proneness of Amlapitta mostly in age group 20-29 years having liking towards salty, spicy and Katu Rasa. Maximum (58) female patients, with 31.03\% who had family history of Amlapitta and $77.78 \%$ patients found to have Kapha-Pitta dominent Prakruti which indicate towards importance of Prakriti and family history of an individual in disease manifestation.
\end{abstract}

Key Words: Amlapitta, Hyperacidity, Atiyoga of Lavana Rasa, salts, common salt, causative factor

\section{Introduction}

Person consumes various tasty foods in daily routine. Salt is one of the main ingredients which maintains taste and enhances flavor of food. Common salt i.e. Samudra Lavan(1) out of different types of salt being universal, is more used for cooking. Use of salts for preservation is significantly seen as it helps to retain flavor of food. It is observed that food items like cheese, chips, sauces, buttermilk, etc. contains variety of salts(2).

Garlic salts (3) are used in salads and Italian dishes like pasta, etc. and also to weaken the meaty smell. But when consumed in excess, it can cause flatulence, heartburn, body odor, burning sensation in throat and mouth. Celery salt (4), a mixture of grounded seeds and table salt or sea salt, is used as a

\section{* Corresponding Author:}

\section{Joshi Mrudula Vinayak}

Professor and HOD, Department of Ayurved Samhita

Siddhanta, Dr D.Y.Patil college of Ayurved and

Research centre, Pimpri, Dr D.Y. Patil Vidyapeeth

(Deemed to be University), Pune, Maharashtra, India.

Email Id: mrudula.joshi@dpu.edu.in food seasoning for stews, salads and potato chips etc. It is often used to prevent food spoilage but it has carcinogenic effects. In excess, it may cause mild allergic reaction to severe effects as anaphylaxis. It can also cause sensitivity to sun. Butter salts (5) is used to give artificial buttery flavor and yellow coloring to popcorns. Kala Namak(6) is mainly used in South Asian countries and useful in treatment of gastro-intestinal diseases and heartburns.

Also in Indian Sciences, Ayurvedic compendia have enlisted different salts i.e., Lavanas under groups Pancha Lavan(7) etc. with their specific properties and therapeutic uses. Saindhava Lavana(8)is best amongst all. It has properties like Laghu, Teekshna, Snigdha, Ruchya. Hence it is useful in treatment of Agni (digestive system), also for Vajikaran. Sauvarchala Lavana is Ushna, Laghu, Ruchya and Vata Anulomaka. Hence it is useful for Pachana, Agni Vardhan, also to alleviate Vata Dosha. Beed Lavana having Laghu, Ushna, Teekshna properties helps in conditions like Ajeerna (indigestion), Shoola (pain). Samudra Lavana is Guru, Avidahi and having Na Ati Ushna Veerya. Romak Lavana has Laghu, Ushna, Teekshna and Bhedana properties. Audbhika Lavana and Panshuja Lavana have Tikta, Katu Rasa (taste). Katu Lavana is 
Joshi Mrudula Vinayak et.al., Excess consumption of Lavana Rasa (Salty taste) - A cause of Amlapitta (Hyperacidity)

a group of 3 types of Lavana having Katu and Chedan property.

Nowadays Amlapitta is one of the common diseases observed in individuals. Vidahi and PittaPrakopi Ahara is mentioned as the Hetu of Amlapitta. Lavana Rasa is described as Vidahi and also due to Tikshna, Ushna and Agneya Guna it causes Pitta-Prakopa. So ultimately Lavana Rasa causes Amlapitta if it is taken in excess quantity.

In Charak Samhita, it is specifically advised to not to use Lavana and Kshara(9) in Atimatra i.e., excess quantity as it causes vitiation of Pitta and Rakta. There occurs Kleennata of Dosha and Dhatus. Also symptoms and side effects of consumption of Lavana in Atimatra is explained. Intake of salt in excess can lead into Amlapitta(10). Hence, this study was conducted to observe the relation between Atiyog of Lavana Rasa as a Hetu of Amlapitta. In a previous observational study similar observation i.e. atiyog of Lavana rasa was noted as one of the cause of Amlapitta in 50\% $(n=1000)$ of total patients (11).

\section{Aim}

To examine whether Atiyoga of Lavana Rasa (common salt) can be a Hetu (causative factor) of Amlapitta.

\section{Methodology}

Total 100 volunteers suffering from Amlodgar; a major symptom of Amlapitta disease, of age group 20-60 years were selected regardless of gender. A structured, pilot tested and validated, 6 item questionnaire prepared for the present work, was used to collect the data. Complete questionnaire was filled by investigator to rule out excess consumption of Lavana Rasa by patients. Patients of Amlapitta not having history of consuming excess Lavana rasa, are not included in the study. It included questions like daily salt intake of individuals, intake of salts on table $>,<1$ teaspoon $(5 \mathrm{gms})$, the frequency of certain substances in diet like pickle, papad, salty chilies. Occasional salty food intake with details- Food items, Frequency, Quantity, Liking of Rasa. Statistical assessment was done on the basis of observed numbers and percentage.

\section{Observations}

Table1-Distribution of 100 patients of Amlapitta according to age and excess consumption of Lavana Rasa

\begin{tabular}{|c|c|c|c|c|}
\hline $\begin{array}{c}\text { Sr.No } \\
\text {. }\end{array}$ & $\begin{array}{l}\text { Age } \\
\text { in } \\
\text { Years }\end{array}$ & $\begin{array}{c}\text { No.of } \\
\text { Amlapitta } \\
\text { patients } \\
\mathbf{N}=100\end{array}$ & $\begin{array}{c}\text { No. of } \\
\text { patients } \\
\text { consuming } \\
\text { excess } \\
\text { Lavana } \\
\text { rasa } \mathrm{N}=62\end{array}$ & $\begin{array}{c}\text { Percentage } \\
\text { of patients } \\
\text { consuming } \\
\text { excess } \\
\text { Lavana Rasa } \\
\text { N=62 }\end{array}$ \\
\hline 1 & $20-29$ & 22 & 18 & 81.81 \\
\hline 2 & $30-39$ & 35 & 22 & 62.86 \\
\hline 3 & $40-49$ & 25 & 12 & \\
\hline 4 & $50-59$ & 18 & 10 & 55.55 \\
\hline
\end{tabular}

Table 2-Distribution of 100 patients of Amlapitta according to Prakruti and excess consumption of Lavana Rasa

\begin{tabular}{|c|c|c|c|c|} 
Sr. & Prakruti & $\begin{array}{c}\text { No. of } \\
\text { patients } \\
\text { N=100 }\end{array}$ & $\begin{array}{c}\text { No. of } \\
\text { patients } \\
\text { consuming } \\
\text { excess } \\
\text { Lavana rasa } \\
\text { N=62 }\end{array}$ & $\begin{array}{c}\text { Total } \\
\text { Percent } \\
\text { age }\end{array}$ \\
\begin{tabular}{|c|c|c|} 
N=62 \\
1
\end{tabular} & & & \\
\hline $\mathbf{1}$ & Vata-Pitta & $\mathbf{3 0}$ & 19 & 63.33 \\
\hline $\mathbf{2}$ & Pitta-Kapha & $\mathbf{1 6}$ & 11 & 68.75 \\
\hline $\mathbf{3}$ & Kapha-Vata & $\mathbf{1 0}$ & 4 & 40.00 \\
\hline $\mathbf{4}$ & Pitta-Vata & $\mathbf{2 1}$ & 13 & 61.90 \\
\hline $\mathbf{5}$ & Kapha-Pitta & $\mathbf{9}$ & 7 & 77.78 \\
\hline $\mathbf{6}$ & Vata-Kapha & $\mathbf{1 4}$ & 8 & 57.14 \\
\hline
\end{tabular}

Table 3- Distribution of 100 patients of Amlpitta according to Gender and family history

\begin{tabular}{|c|c|c|c|c|c|}
\hline Gender & No. of & \multicolumn{4}{|c|}{ Family history } \\
& Patients & Positive & Percentage & Negative & Percentage \\
\hline Male & 42 & 2 & 4.76 & 40 & 95.24 \\
\hline Female & 58 & 18 & 31.03 & 40 & 68.97 \\
\hline Total & 100 & 20 & 20 & 80 & 80 \\
\hline
\end{tabular}

Table 4-Distribution of patients of Amlapitta according to Aharaja Hetu

\begin{tabular}{|c|c|c|c|}
\hline $\begin{array}{l}\text { Sr. } \\
\text { No. }\end{array}$ & Type of Aharaj Hetu & $\begin{array}{l}\text { No. of } \\
\text { patients }\end{array}$ & $\begin{array}{l}\text { Total } \\
\text { percent } \\
\text { age }\end{array}$ \\
\hline 1 & Lavana Rasadhikya & 62 & 62 \\
\hline 2 & Katu Rasadhikya & 56 & 56 \\
\hline 3 & Amla Rasadhikya & 16 & 16 \\
\hline 4 & Spicy food (Katu+ Lavana) & 58 & 58 \\
\hline 5 & Vidahi Anna (Katu+Lavana+oil) & 60 & 60 \\
\hline 6 & $\begin{array}{l}\text { Ati Ruksha-Chat masala } \\
(\text { Lavana }+ \text { Katu })\end{array}$ & 30 & 30 \\
\hline 7 & $\begin{array}{l}\text { Ati Snigdha- Oily (Katu+ } \\
\text { Lavana) }\end{array}$ & 56 & 56 \\
\hline 8 & Paryushitanna sevan & 22 & 22 \\
\hline 9 & Milk products, Dahi & 26 & 26 \\
\hline 10 & Ati Guru & 34 & 34 \\
\hline
\end{tabular}

Table 5 - Distribution of 100 patients of Amlpitta according to Rasa priti

\begin{tabular}{|c|c|c|c|}
\hline Sr.No. & Type of & No. of & Total \% \\
\hline 1 & Amla & 16 & 16 \\
\hline 2 & Lavana & 28 & 28 \\
\hline 3 & Katu & 36 & 36 \\
\hline 4 & Other & 20 & 20 \\
\hline
\end{tabular}

\section{Discussion}

The number of Amlapitta patients who consumed Lavana Rasa in excess according to the age group showed maximum number of patients i.e. $81.81 \%$ in age group $20-29$ years. This shows the indulgence of this age group population towards food items having variety of salts. The percentage was less in age group 40-49 years as there is less addiction towards salty food.

Observation regarding the dominance of Dosha in Prakruti as per table 2- out of 100 patients of Amlapitta, maximum 30 patients had Vata-Pitta dominent Prakruti and 21 patients had Pitta-Vata 
dominance. While 7 out of 9 patients, i.e. $77.78 \%$ patients found to have Kapha-Pitta dominent Prakruti who suffered from Amlapitta due to excess consumption of Lavana rasa. This indicates towards the dominance of Drava Guna in Lavana Rasa and its implication on Prakruti.

The quest of gender and family history (table3), expressed maximum (58)female patients, with $31.03 \%$ who had family history of Amlapitta; whereas only in $4.76 \%$ out of 42 male patients, family history was found.

Out of 100 patients of Amlapitta, causative factors to be noted are Lavana Rasadhikya in 62 patients whereas Vidahi Anna followed by spicy food and oily food were found in 60, 58, 56 number of patients respectively. Here Vidahi, spicy and oily food is combination of Lavana, Katu Rasa and oil. It is really difficult to actually count the amount of any particular Rasa in diet. Still the combinations studied in present work are textually defined as causative factors and observed in this cross sectional study.

In 100 patients of Amlapitta, 36\% patients had temptation towards Katu Rasa which was observed as maximum; followed by $28 \%$ patients liked Lavana Rasa, 16\% patients Amla Rasa which was found to be minimum. In remaining $20 \%$ patients, liking towards Rasa other than mentioned above i.e. Madhura, Tikta, Kashay was observed.

In a previous observational survey study on Rasa-Atiyoga similar observation i.e. Atiyoga of Lavana rasa was noted as important cause of Amlapitta in $50 \%(\mathrm{n}=1000)$ of total patients (11). This supports the present work observation.

\section{Conclusion}

From the present cross sectional study, it can be concluded that even though the disease Amlapittal Amlika is not separately described in special chapter in Charak and Sushrut Samhita, but mentioned as Lakshana (symptom) of Atiyoga (excessive intake) of Lavana Rasa. Features of Amlika are similar to that of Amlapitta which can interpret as Hyperacidity according to modern sciences. There is proneness of Amlapitta mostly in age group 20-29 years due to liking towards salty, spicy food and Katu Rasa. Maximum (58) female patients, with $31.03 \%$ who had family history of Amlapitta and $77.78 \%$ patients found to have Kapha-Pitta dominant Prakruti which indicate towards importance of Prakriti and family history of an individual in disease manifestation. Younger generation seems to have more liking towards cheese, chips, sauces, etc. They become prone for ill effects of excess consumption of Lavan Rasa like Amlapitta, Khalitya, etc. For the sake of prevention awareness programs and studies can be designed.

\section{References}

1. Shilpa Nimbal, Umapati C. Baragi, \& Jyothi Alias Jyotsna; Lavana Varga in Ayurveda; Journal of Ayurveda and Integrated Medical Sciences; 2019; 4(03); 79-83. Retrieved from https://jaims.in/jaims/ article/view/625

2. Amul Cheese :--https://www.google.com/url? $\mathrm{sa}=\mathrm{i} \& u r \mathrm{l}=\mathrm{https} \% 3 \mathrm{~A} \% 2 \mathrm{~F} \% 2 \mathrm{Fwww}$.dhirajbakers.com $\% 2 \mathrm{~F} \quad \mathrm{p}$ r cheese\&psig=AOvVaw2JiJJF6NbOVuYRFSRnTwH E\&ust $=1632552440877000 \&$ source $=$ images\& $\mathrm{cd}=\mathrm{vf}$ e\&ved=0CAsQjRxqFwoTCIiS5_SBl_MCFQAAAA AdAAAAABAI - dated on 18/10/202 1 at 12:54 IST Balaji wafers :--https://www.google.com/url? $\mathrm{sa}=\mathrm{i} \&$ url $=$ https $\% 3 \mathrm{~A} \% 2 \mathrm{~F} \% 2 \mathrm{Fworld}$.openfoodfacts.or g\%2Fproduct $\% 2$ F8906010501570\%2Fbalaji-waferscrunchex\&psig=AOvVaw312GaCrZHZ-9sJzinFHFf $1 \&$ ust $=1632552715309000 \&$ source $=$ images \& $\mathrm{cd}=$ vfe \&ved=0CAsQjRxqFwoTCPC10feCl_MCFQAAAA AdAAAAABAX - dated on 18/10/2021 at 12:54 IST

3. https://food.ndtv.com/food-drinks/indian-cookingtips-how-to-make-garlic-salt-at-home-and-whyyou-must-include-it-in-your-diet-2116653 - dated on $18 / 10 / 2021$ at $12: 50$ IST

4. https://en.wikipedia.org/wiki/Celery_salt - dated on 18/09/2021 at 12:30 IST

5. https://en.wikipedia.org/wiki/Butter_salt\#cite note-2 - dated on 18/09/2021 at 12:30 IST

6. https://en.wikipedia.org/wiki/Kala_namak\#Uses dated on 20/09/2021 at 15:09 IST

7. Yadavji Trikamji Acharya, Agnivesha's Charaka Samhita with Ayurved Deepika commentary of Chakrapanidatta, Ed.,Chaukhambha Sanskrit Sansthan, Varanasi, Reprint, Sutrasthana, 2015; $1 / 88$

8. Yadavji Trikamji Acharya, Agnivesha's Charaka Samhita with Ayurved Deepika commentary of Chakrapanidatta, Ed., Chaukhambha Sanskrit Sansthan, Varanasi, Reprint, Sutrasthana, 2015; 25/38

9. Yadavji Trikamji Acharya, Agnivesha's Charaka Samhita with Ayurved Deepika commentary of Chakrapanidatta, Ed.,Chaukhambha Sanskrit Sansthan, Varanasi, Reprint, Vimansthana, 2015; $1 / 15$

10. Yadavji Trikamji Acharya, Agnivesha's Charaka Samhita with Ayurved Deepika commentary of Chakrapanidatta, Ed., Chaukhambha Sanskrit Sansthan, Varanasi, Reprint, Sutrasthana, 2015; 26/ (3) 43

11. http://www.pijar.org/articles/archive/ 8.Dr.Vivek\%20Gokhale.pdf -dated on 20/09/2021 at 15:15 IST. 